\title{
Analyses of Impacting Factors of ICT in Education Management: Case Study
}

\author{
Bekim Fetaji \\ University Mother Teresa, Informatics, Skopje, 1000, Macedonia \\ Email: bekim.fetaji@unt.edu.mk \\ Majlinda Fetaji and Mirlinda Ebibi and Samet Kera \\ South East European University, Contemporary Sciences, Tetovo, 1200, Macedonia \\ University Mother Teresa, Informatics, Skopje, 1000, Macedonia \\ Email: m.fetaji@seeu.edu.mk \{mirlinda.ebibi, samet.kera\}@unt.edu.mk
}

Received: 01 December 2017; Accepted: 10 January 2018; Published: 08 February 2018

\begin{abstract}
Research studies and attitudes towards ICT use in education management are shifting, and often significantly. This is likely to have a major impact upon ICT and education management. However, the real significance of the impact for educational management has yet to be seen within this research study. The focus of the research study is to investigate and analyses the ICT usage in Education Management. ICT in teaching has an important role and its impact on the advancement of educational processes related to effective teaching and learning, and modern research in this field is almost irreplaceable. Another important element is the use of different software platforms that facilitate learning visible and make it more concrete, more practical and applicable to everyday life. In order to analyze the data a combination of qualitative and quantitative methodology has been used. In order to analyze this, Case study analysis of high schools in city of Skopje, Macedonia is realized. Insights and recommendations are provided.
\end{abstract}

Index Terms-ICT impact in education, Management of education, evaluation of technology enhanced education

\section{INTRODUCTION}

According to [2] for years now the schools are making efforts for the integration of ICT with a substantial investment in hardware and software.

In recent years the Ministry of Education seems to have gone to another level with investments in electronic platform to facilitate the integration of ICT in schools.

Integration of ICT in integral system operation activities in all areas and subjects in the first requires the use of existing equipment and secondly the development of ideas on what traditional technology can be used new technologies to learning [7].

ICT in teaching has an important role and its impact [3] on the advancement of educational processes related to effective teaching and learning, and modern research in this field is almost irreplaceable. Another important element is the use of different software platforms that facilitate learning visible and make it more concrete, more practical and applicable to everyday life [6]. Of course, the use of ICT in teaching practices cannot be imagined without the continuous professional development of teachers [8], to increase competence in the use of ICT and global tracking technological innovation in the field of education [4].

"The integration of ICT in all major institutions and social organizations means that the need to equip young people with the capacity to understand and exploit the potential of such environments is not an alternative, but it is now a necessity" [10]

Substantial benefits to students' achievements are more accessible when using ICT is planned, structured and effectively integrated.

\section{LITERATURE REVIEW}

This current literature review provides an investigation to the research published in the field of ICT $[14,15]$ and educational menagment $[2,7,12]$, identifies some key issues and emerging messages, and suggest priority areas for the research study undertaken [14].

Key emerging messages [1-8] include the following: the importance of ICT to society and to future prospects is clear within the educational literature, but the real significance of this for educational management has yet to be seen within this research study. The educational management literature is beginning to indicate that attitudes towards ICT are shifting, and often significantly, which is likely to have a major impact upon ICT and school management. The importance of communication systems for education is being highlighted within the literature increasingly [10-15], but the personnel effects of this outcome are not yet being studied to any great extent [5], and it would appear to be difficult to find case study examples from which to extrapolate at this present time. Messages arising from the general management and management of change literature appear to be relevant and pertinent within the educational, and ICT and management, areas, but there are a number of key 
concerns which suggest that some caution needs to be taken with regard to certain areas of that literature [11] in particular personnel, financial, and strategic aspects. [3] identified a range of management implications of using on-line resources in schools and in homes. A particular outcome highlighted the need for groups to consider purpose carefully before investing heavily in communication technologies, since practical use did not merge unless users had some pre-existing concepts of potential applications. The impact upon management when laptop technologies were used was reported further in a series of later studies $[2,4]$.

Of particular note was the outcome that parents [8] would be likely to use ICT more in the future for communication with schools, and that this would require managing, just as any other area of important relationship needs to be managed between homes and schools as disccused by $[8,10]$.

[3] used the term online learning throughout and he defines online learning as "the use of the Internet to access learning materials; to interact with the content, instructor, and other learners; and to obtain support during the learning process, in order to acquire knowledge, to construct personal meaning, and to grow from the learning experience";

In his synopsis of the Superhighways Evaluation report, [1] reported on the clear need for positive and supportive management to enable all those involved in educational endeavours to gain from the potential that ICT can bring to learning and teaching. He indicated the pervasive effect that ICT was having upon the pilot schools being studied, and the implications that this would have for the future. The report highlighted the need for all those involved in educational systems (whether they be parents, pupils, teachers, managers, or supporters) to become conversant with the concepts being introduced and developed, to become aware that their needs would enlarge and widen, and that their awareness of the potential that communication systems could offer educational outcomes would need to be enhanced in order for each group to utilise and work together for specific purpose. Twining reports in one article on aspects of ICT and school management in the primary school sector specifically. He reports on the use of a particular technique as a means to bring strategic vision and implementation need closer together. He argues that strategic vision is important, but that implementation requires the use of techniques which will offer the teacher more opportunity to plan for educational practice.

[6] bring together a series of studies from a range of countries that explore current features of computerized school information systems, their implementation in a range of schools, the outcomes of this implementation, and implications for the future in terms of further research. However, it is clear from this literature that most concern currently is being focused on data entry and collation, rather than upon data transfer or analysis as discussed by [11].
According to [12] current research on the impacts of ICTs on student achievement yields few conclusive statements, pros or con, about the use of ICTs in education and education management. Different studies as discussed by [6] have shown that even in the most advanced schools in industrialized countries, ICTs are generally not considered central to the teaching and learning process. However, there appears to be a mismatch between methods [2] used to measure effects and the type of learning promoted [4]. Standardized testing, for example, tends to measure the results of traditional teaching practices, rather than new knowledge and skills related to the use of ICTs. "Of the teachers interviewed on the effectiveness of ICT in education majority of them felt that introduction and use of ICT adequately will be extremely effective in children "s learning and achievement" [12].

According to [12] more research needs to be conducted to understand the complex links between ICTs, learning, and achievement. Again, on the question of impact of audio and visual ICT documents used in the learning process, research shows that surprisingly little documentation is available on the use and impact of video in education [12].

According to the teachers mainly focus on the development of technical ICT skills, whereas the ICT curriculum centers on the integrated use of ICT within the learning [5] and teaching process. When resources become used within homes and schools to the extent that is now happening [9], for example, it is unclear where responsibilities might lie, or where educational activity begins or ends.

Therefore analyses of the impact of ICT in education management is missing new relevant insights and needs to be further analysed and reviewed. In order to do this we have undertaken this study to add additional insights into the imapct of ICT in education management.

\section{RESEARCH METHODOLOGY}

The research methodology used within the research study is quantitative research. Primary quantitative data has been mainly collected from questionnaires particularly designed for this research which has been distributed to the management and teachers of 2 school institution.

The target group were teachers of different subjects and schools. The research methodology is based on the questionnaire instrument which has been distributed to 2 educational institutions-high schools Zef Lush Marku and Arsenie Jovkov in the municipality of Skopje.

The questionnaire consisted of 32 questions, where: 9 questions - consisting basic information and other questions have been distributed for assesing the specific impacting factors.

40 Questionnaires have been distributed to school Principles and recived 39 of responses from them, and waited approximately 2 months for the responses. 


\section{CASE Study AnAlysis}

In order to analyze the impacting factors in usage of ICT in education management a Case study analysis of high schools in city of Skopje, Macedonia is realized.

The revealing of the improper use of technology in teaching practices is reflected in the questionnaire where the use of technology in teaching school for 21 responded never, 43 times, 36 on average, and only 15 always.

This level of knowledge is not justified by the fact that the sample used in the age group 57\% are new and $91 \%$ have a personal computer at home and have attended several training programs for computer work.

The rate of use of the applications of Office that represents the foundation of computer, according to survey results proves to be low, which is reflected in the quality of teaching and learning concrete and practical research, although $73 \%$ of the sample of teachers are faculty and $12 \%$ have professional master and $25 \%$ of them are with HPS. As well as their teaching experience is another indicator that should better reflect the level of use of ICT in teaching. Where 69\% have 1-19 years' experience of teaching experience, $18 \%$ of 20-29 years' experience and over 30 are $13 \%$ of the target group. Also these results are questionable due to the fact that $51 \%$ have completed the training ECDL while $49 \%$ have attended other trainings.

Regarding the use of the Internet is a fundamental resource for the use of technology in teaching practices are very worrying results because $41 \%$ of respondents said they do not use at all.

The result of the test preparation for students is more gratifying because $60.86 \%$ stated that the tests produce themselves. Contrary to what a few of them use technology to prepare for the presentation of teaching units where only $21.73 \%$ said they always use.

\section{RESULTS}

Out of the 35 questionnaires distributed to high school principals received 34 responses. The rate of use of the applications of Office that represents the foundation of computer, according to survey results proves low beginner level, which is reflected in the overall management of the school, although $22 \%$ of directors are professional qualifications master and $41 \%$ of them have over 8 years experience in leadership.

As for this other software, such as software for the preparation and management of school schedules and project management software for schools (schools that can improve performance) it appears that the level of their use is very disturbing, where only two schools $(6 \%)$ use the software for preparation of schedules electronically and not in full measure. Even more alarming is the result of Internet usage where $50 \%$ have basic knowledge.

The result of processing the reports came out very satisfactory $91 \%$ in electronic form, as a result that directors engage subordinates, in most cases $(45 \%)$ teachers for the preparation of these reports. These reports are often delayed by the results for two reasons: not the best approach to technology (72\%) and neglect of dependents $(28 \%)$.

Electronic communication internally and externally according to the results of the questionnaire carried out to the extent that $44 \%$ referring assistance again subordinates.

Gender - in terms of gender structure of school principals $75 \%$ of them are male and $25 \%$ female, which means that significantly male-dominated.

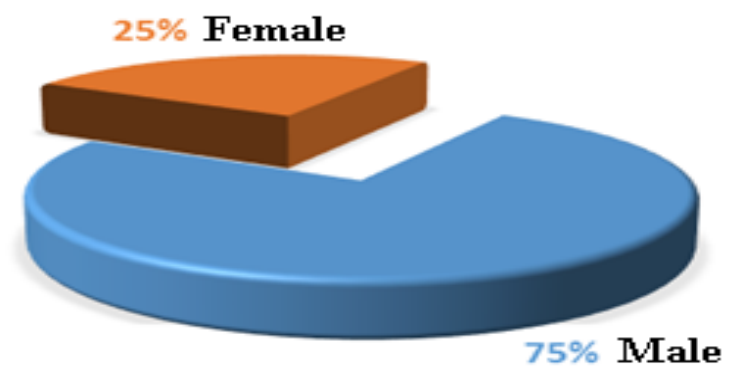

Fig.1. Gender Analyses

Age - From graphic coverage in the following Fig. we see that the age over 51 years dominates with $81 \%$ in the leading structures of educational institutions in the municipality of Skopje, and this comes out that is not a good indicator of the level of use of technology.

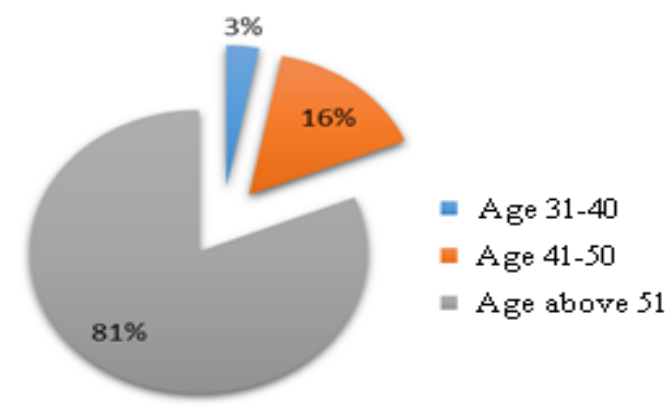

Fig.2. Analyses of Age Distribution

Experience - From the result appear in the statement of experience $41 \%$ of school principals have extensive experience in leadership, then over 8 years since one hand is a positive indicator, as this experience helps in leadership, from the other side of the mirror age did handicapped in the use of technology.

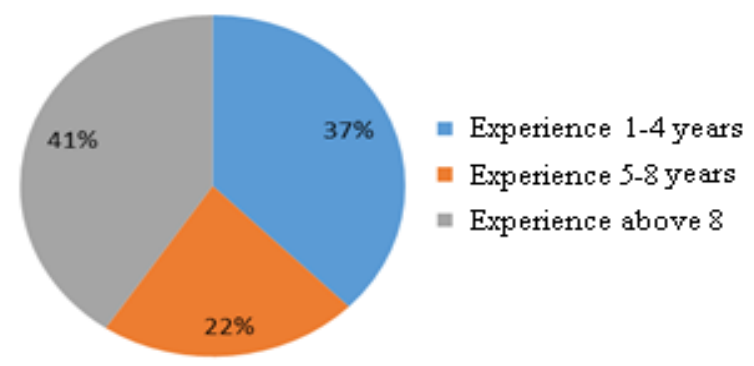

Fig.3. Analyses of Work Experience 
Professional qualification - Qualification structure of school directors in Skopje is high, where 22 of them are in college 4 years, 7 to master and only 3 with college.

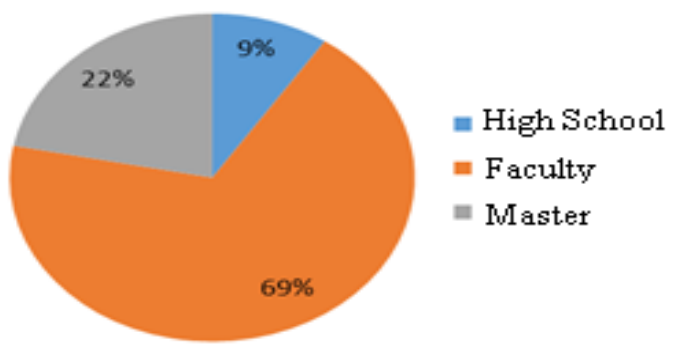

Fig.4. Analyses of Professional Qualification

This indicator should affect the efficient use of technology, but considering that all these preparations are social profiles, contributing to minimal use of technology.

Access to computers - Based on the results presented from the survey results that all principals of schools are equipped with computers, which is an indication of very important on the one hand and a disturbing indicator on the other hand, since the level of use their very low.

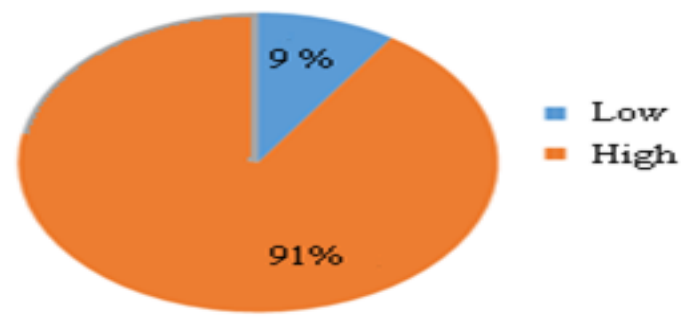

Fig.5. Analyses of Access to Computers

Long experience as Director, Computer possession, following some training in technology is inconsistent with the level of full use of technology for the management and creation of climate use in schools.

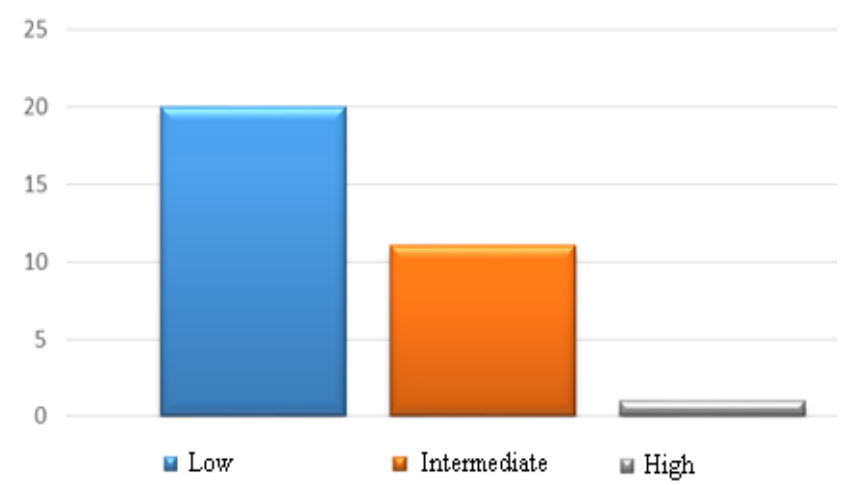

Fig.6. Analyses of Computer Skills level

Computer skills - from $63 \%$ of directors have little knowledge in the use of technology, despite the fact that all possessed a computer, 34\% and 3\% average knowledge of enjoyable knowledge. The following image is reflected in the rate of computer ownership by directors.
MS Word - 34\% of beginner users and 66\% advanced of initial users, it is known that the use of this application is more than necessary.

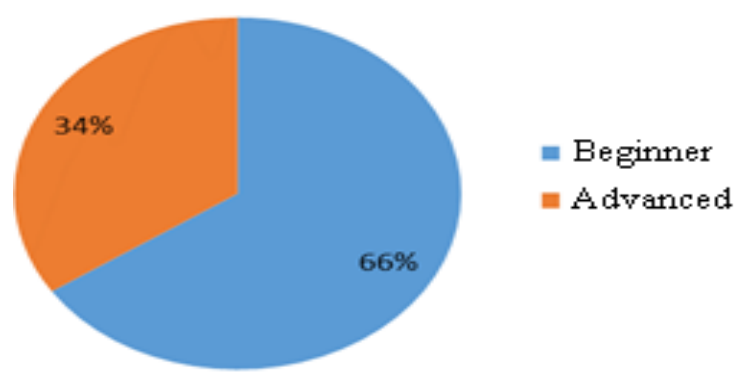

Fig.7. Analyses of usage of Word Text processor

MS Excel - worrisome is the fact that $53 \%$ of school principals at all do not use Excel application, given that the majority of statistical reports issued by this.

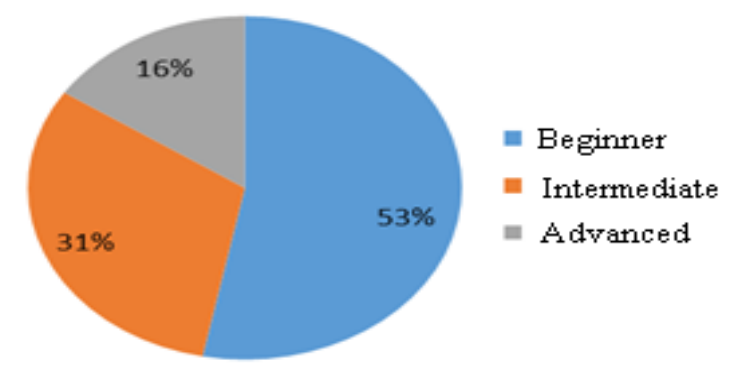

Fig.8. Analyses of Excel usage

MS PowerPoint - Even this mass application unsatisfactory use directors, which will help a lot for the preparation and presentation of data.

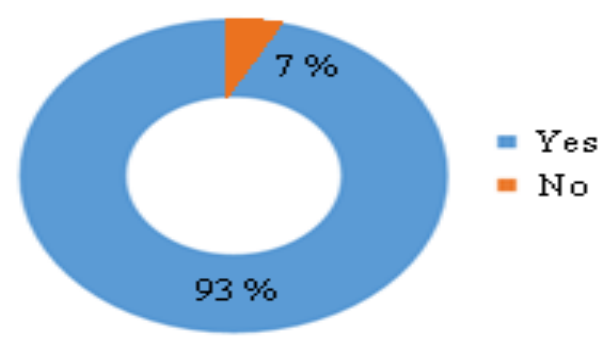

Fig.9. Analyses of PowerPoint usage

MS Access - 87\% of directors who do not use this app is very high, given that all institutions should have database.

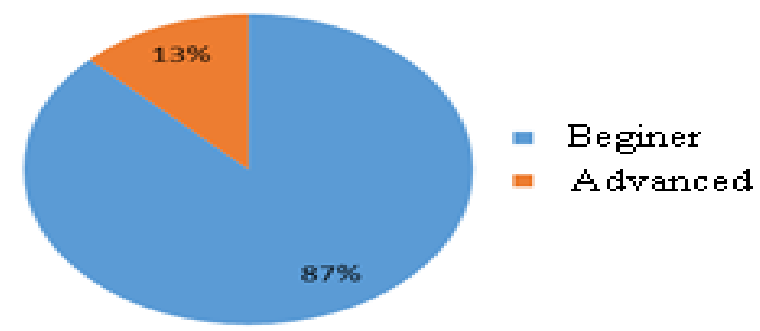

Fig.10. Analyses of Access usage 
MS Project - All schools in different time period the developed projects. The best way of managing these projects is to use applications which will help greatly as MS Project. None of the directors do not use this application that would facilitate the work on the projects forwarded.

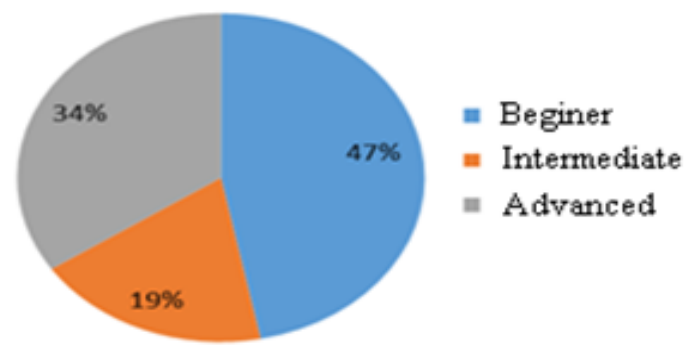

Fig.11. Analyses of Project usage

Schools spend great time in preparation, testing, distribution (to teachers, students and parents). Also schools also face difficulties in adjustment to schedule and its eventual modification. It often happens that two weeks before the start of the school year to spend only testing schedule. This is a handicap as a result of not using different software that enable easy creation and management of school hours in the shortest time possible. Also this time can also publish on the website of the school.

Website - 50\% of those who are beginners in the use of the Internet is alarming, because all communication nowadays is oriented towards and through Internet technologies. Everything in the world of technology today is preceded by communication via the Internet. Development and advancement of all processes that occur in school is dependent primarily by communication through internet technologies.

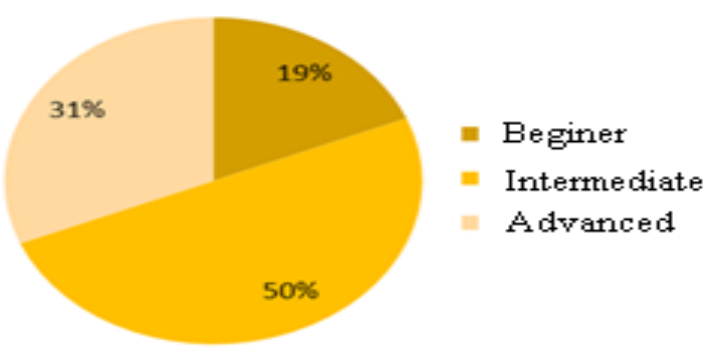

Fig.12. Analyses of Internet usage

Reports - Measure the percentage of $91 \%$ electronic reporting is inconsistent with the computer skills of directors. To this percentage is due to staff-subordinate directors engage others to prepare reports on electronically.

Compiler reports - greatly principals hire teachers for the preparation of reports. This result gives us realize even one of the reasons why the level of technology use is low, so they are upheld to their subordinates and this did not make them to engage and commit themselves more in the use of technology, given the fact that they have the legal obligations which sets out the duties of school principals, as p.sh management database to school, reporting through EMIS 1 -s, statistical reports, descriptive, analytical etc. The Fig. shown on the next page, seen rates makers electronic medical reports.

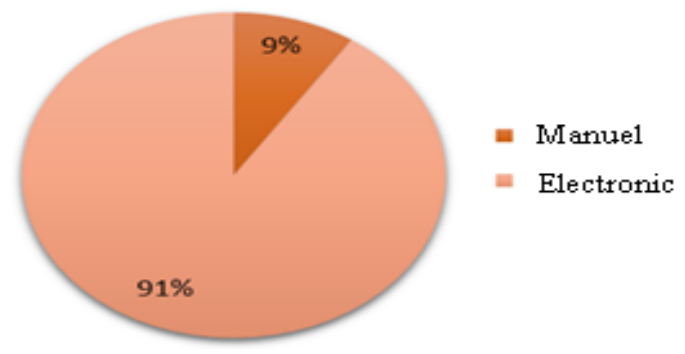

Fig.13. Analyses of Reporting

Delays reports - Clearly not the best approach to technology affects the delayed reports. These delays cause reporting problems because they know that these reports have their hierarchy of school - education director - Minister.

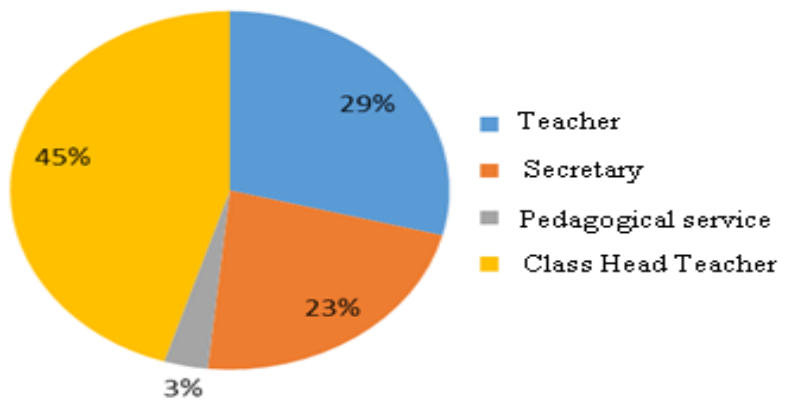

Fig.14. Analyses of Daily Reports

Communication - The tabular overview of this communication appears that the directors of subsidiaries engage in most cases teachers stand out because the result that $44 \%$ of the media use that is inconsistent with the level of use of technology by the directors.

Table 1. Coverage of exploitation technologies of communication directors expressed in numbers and percentages

\begin{tabular}{|c|c|c|}
\hline \multicolumn{3}{|c|}{$\begin{array}{l}\text { Coverage of exploitation technologies of communication directors } \\
\text { expressed in numbers and percentages }\end{array}$} \\
\hline Communication technologies & $\mathrm{Nr}$. & $\%$ \\
\hline phone & 2 & 6 \\
\hline Phone \& Hard Copy & 3 & 10 \\
\hline Phone, mail Hard Copy \& & 11 & 34 \\
\hline Phone, mail \& Social Networks & 2 & 6 \\
\hline Phone, Hard Copy, mail \& Social Networks & 14 & 44 \\
\hline
\end{tabular}


The outlook for technology - indicators that give positive signs for the use of technology and its integration in school is the fact that all the directors in question "Will the use of technology to help management" responded positively. This gives with the understanding that they are aware of the role that the use of technology to facilitate the performance and management duties in their schools. In relation to the degree of knowledge and experience in their results that only an opinion declared not a necessity in which you should invest continuously in this direction. Directors have the opportunity to invest in knowledge for technology to do without can be large, since all possess computer, are all the time in school, have teaching technology from whose experience can benefit, provided various trainings can cooperate with each - other.

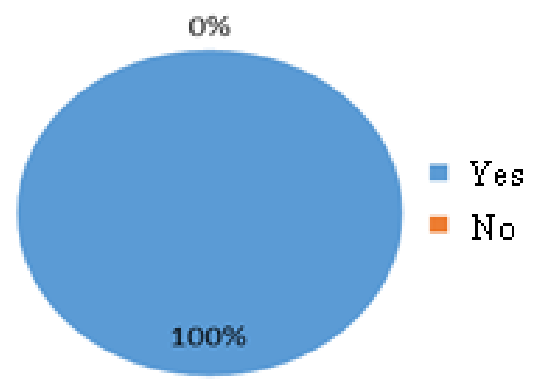

Fig.15. Impact of Technology in Management

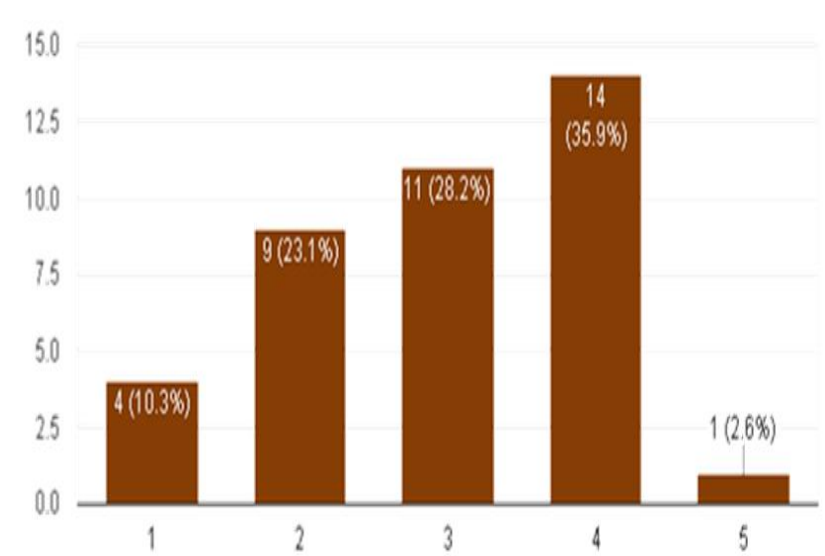

Fig.16. How do you grade the IT level of usage? (1-Bad, 5-Excellent)

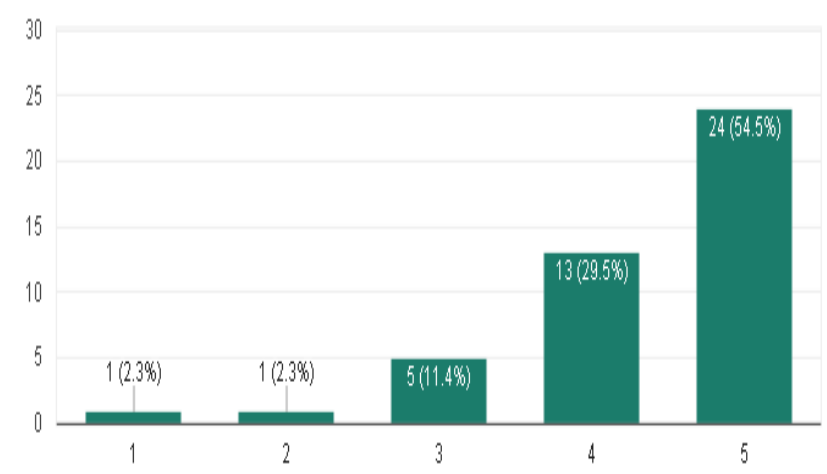

Fig.17. Estimation of Teachers attitude towards use of ICT in your own department. (1-Bad, 5-Excellent)
Technology Comments: A large number of principals surveyed (50\%), marked comments about the importance of using technology in school.

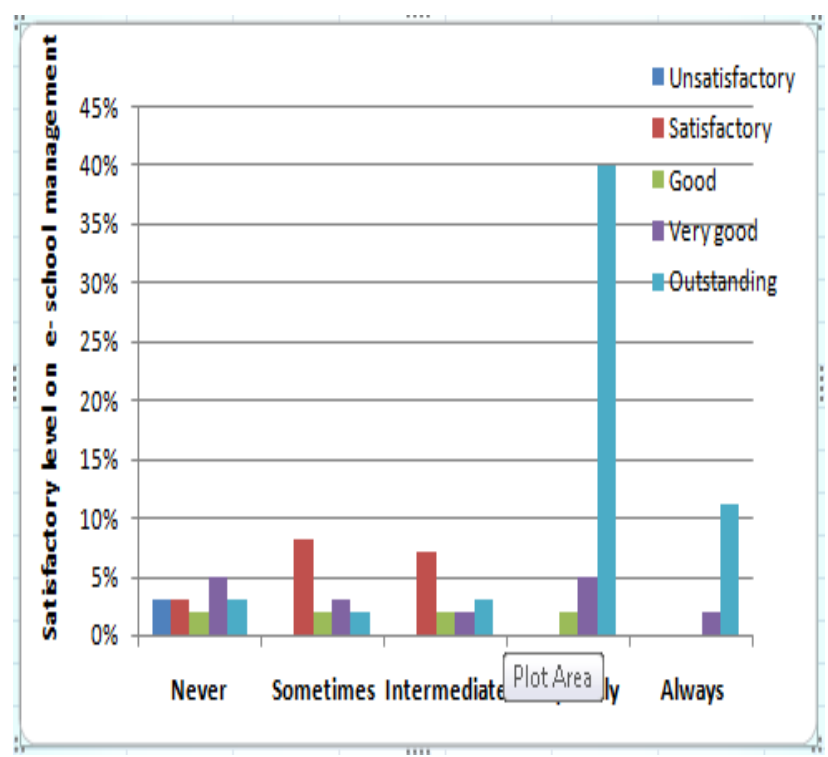

Fig.18. Satisfaction level towards use of ICT vs. previous

We have used the regression equations to measure the statistical significance of the data obtained and their relationship. The results of regression are shown in the following Tables below.

Table 2. Regression level of positive impact of ict on schools management . $X_{1}=$ get information in time/ at any time

\begin{tabular}{|c|c|c|c|c|c|c|}
\hline Source & SS & df & MS & \multirow{3}{*}{\multicolumn{3}{|c|}{$\begin{array}{lr}\text { Number of obs }=60 \\
\mathrm{~F}(1,58) & =72.96 \\
\text { Prob }>\mathrm{F} & =0.000 \\
\text { R-squared } & =0.557 \\
\text { Adj R-squared } & =0.549\end{array}$}} \\
\hline Model & 52.77 & 1 & 52.77 & & & \\
\hline Residual & 41.95 & 58 & 0.723 & & & \\
\hline Total & 94.73 & 59 & 1.605 & \multicolumn{3}{|c|}{ Root MSE $\quad=0.850$} \\
\hline reliable & Coef. & $\begin{array}{l}\text { St } \\
\text { Error }\end{array}$ & $\mathrm{t}$ & $P>|t|$ & \multicolumn{2}{|c|}{$\begin{array}{l}\text { [95\% Conf. } \\
\text { Interval] }\end{array}$} \\
\hline getinfo & 0.822 & 0.963 & 8.54 & 0.000 & 0.630 & 1.01 \\
\hline _cons & 0.996 & 0.342 & 2.91 & 0.005 & 0.310 & 1.68 \\
\hline
\end{tabular}

Now we have to test how good this regression equation predicts values of $\mathrm{y}$, for given values of $\mathrm{Xi}, \mathrm{i}=1, \ldots, 5$.

Here we can see that the reliability is at $95 \%$ of confidence factor.

Results are presented in the following regression equations:

$$
\begin{gathered}
Y=0.99+0.82 * X 1, Y=1.11+0.76^{*} X 2 \\
Y=1.09+0.76^{*} X 3, Y=1.34+0.68^{*} X 4 \\
Y=1.27+0.68 * X 5
\end{gathered}
$$


Table 3. Regression level of satisfaction level of use of ict $x_{2}=$ check status in time / at any time

\begin{tabular}{|c|c|c|c|c|c|c|}
\hline Source & SS & df & MS & \multirow{4}{*}{\multicolumn{3}{|c|}{\begin{tabular}{rr}
\multicolumn{2}{c}{ Number of obs $=60$} \\
$\mathrm{~F}(1,58)$ & $=97.64$ \\
Prob $>\mathrm{F}$ & $=0.000$ \\
R-squared & $=0.627$ \\
Adj R-squared & $=0.621$ \\
Root MSE $\quad=$ & 0.780
\end{tabular}}} \\
\hline Model & 59.43 & 1 & \multirow{2}{*}{$\begin{array}{l}59.43 \\
0.608\end{array}$} & & & \\
\hline Residual & 35.30 & 58 & & & & \\
\hline Total & 94.73 & 59 & 1.605 & & & \\
\hline reliable & Coef. & $\begin{array}{l}\text { St } \\
\text { Error }\end{array}$ & $\mathrm{t}$ & $P>|t|$ & [95\% & \\
\hline getinfo & 0.682 & 0.069 & 9.88 & 0.000 & 0.544 & 0.82 \\
\hline _cons & 1.276 & 0.271 & 4.70 & 0.005 & 0.732 & 1.82 \\
\hline
\end{tabular}

The probability of the F statistic, the test for statistical significance of the regression equation (an F-value $>4.0$ is usually statistically significant), for which we got the values of $\mathrm{Fi}=72,93,70,93,97, \mathrm{i}=1, \ldots .5$, means that the regression equations help us to understand the relationship between each e-service $\mathrm{Xi}$ and $\mathrm{y}$.

\section{CONCLUSION}

Analyses of the impact of ICT in education management is missing new relevant insights and needs to be further analysed and reviewed. In order to do this we have undertaken this study to add additional insights into the imapct of ICT in education management.

In summary, we have performed both an experimental and theoretical study of the analyses of ICT usage in School Management in Macedonia.

Different findings have suggested that although ICT can improve learning, there are a number of issues that need to be considered if such technology will eventually make the difference. Therefore, care should be taken in this broad level, in where and how and what the impact level will be. There are several issues and impacting factors that need to be taken under consideration. First is the effect of "interrelated integration" of ICT compared with other interventions, the second is the effect of the provision and use of ICT at a general level. In order to analyze this, Case study analysis of high schools in city of Skopje, Macedonia was realized.

The rate of use of the applications of Office that represents the foundation of computer, according to survey results proves low - beginner level, which is reflected in the overall management of the school, although $22 \%$ of directors are professional qualifications master and $41 \%$ of them have over 8 years experience in leadership.

As for this other software, such as software for the preparation and management of school schedules and project management software for schools (schools that can improve performance) it appears that the level of their use is very disturbing, where only two schools (6\%) use the software for preparation of schedules electronically and not in full measure. Even more alarming is the result of Internet usage where $50 \%$ have basic knowledge. The result of processing the reports came out very satisfactory $91 \%$ in electronic form, as a result that directors engage subordinates, in most cases $(45 \%)$ teachers for the preparation of these reports. These reports are often delayed by the results for two reasons: do not use or have frequent approach to technology (72\%) and neglect of dependents (28\%). Electronic communication internally and externally according to the results of the survey carried out to the extent that $44 \%$ referring assistance again subordinates. School leaders principals to move very little use of technology and the opportunities that technology provides for more efficient management of the school. Driving school in most cases break down as a result of access to school directors in relation to technology and integrate it into their daily work.

Main issues that have been identified within the research study regarding ICT impact on education management are: shifting pedagogies from classical to e-learning,; need to redesign curriculums to incorporate ICT and new assessment methodologies and assesment tools, increased volume of work of teachers with using ICT in teaching, improving teachers attitudes and skills towards use of ICT, new chalenges emposed by the technology infrastructure, new volume of work previosly not exisiting like management communication with parents and increased quires. All these contribute to the optimal use of ICTs in education management.

Directors have a basic knowledge of working on computers in a move affecting technological developments in school, difficulties in presenting reports, designs and project management schedules and school, multidimensional communications difficulties, etc. Often their work obligations carry subordinates whose cause obstacles in fulfillment of the obligations in their work. Using technology from principals direct impact in creating a positive school climate for technology integration and professional and efficient management.

\section{REFERENCES}

[1] Brooker, L. (2003). Integrating IT technologies in UK classrooms: Lessons for teachers from early years practitioners. Childhood Education,

[2] Condie, R., Munro, B., Seagraves L., \& Kenesson, S. (2007). The impact of ICT in schools - a landscape revieë. Becta Research, January 2007. Retrieved December 13, 2007

[3] Cuttance, P (2001) "Information and Communication Technologies" School Innovation: Pathway to the Knowledge Society, Department of Education, Training and Youth Affairs pp.73-100.

[4] Duhaney, D.C. (2001). Teacher Education: Preparing Teachers to Integrate Technology. International Journal of Instructional Media.

[5] Dushyanthi U. Vidanagama,(2016),"Acceptance of ELearning among Undergraduates of Computing Degrees in Sri Lanka", International Journal of Modern Education and Computer Science(IJMECS), Vol.8, No.4, pp.25-32, 2016.DOI: $10.5815 / \mathrm{ijmecs} .2016 .04 .04$

[6] Ganesh, T. G. \& Berliner, D. C. (2005). Practices of computer use in elementary education: Perceived and 
missed opportunities. In D. Wray (Chair), ICT in education. Paper presented at the European Association for Research on Learning and Instruction 2005 Biennial Conference, Nicosia, Cyprus

[7] Hamza O. Salami, Ruqayyah S. Ibrahim, Mohammed O. Yahaya, (2016),"Detecting Anomalies in Students' Results Using Decision Trees", International Journal of Modern Education and Computer Science(IJMECS), Vol.8, No.7, pp.31-40, 2016.DOI: 10.5815/ijmecs.2016.07.04

[8] Kozma, R.J. (Ed). (2003) Technology, innovation, and educational change: a global perspective. A report of the Second Information Technology in Education Study (SITES)

[9] M. Rizwan Jameel Qureshi, M. Kashif, (2017), "Adaptive Framework to Manage Multiple Teams Using Agile Methodologies", International Journal of Modern Education and Computer Science(IJMECS), Vol.9, No.1, pp.52-59, 2017.DOI: 10.5815/ijmecs.2017.01.06

[10] M. Wasif Nisar, Ehsan Ullah Munir and Shafqat Ali shad, (2011), Usage and Impact of ICT in Education Sector; A Study of Pakistan, Australian Journal of Basic and Applied Sciences, 5(12): 578-583, 2011 ISSN 1991-8178

[11] Mai Abdrabo, Mohammed Elmogy, Ghada Eltaweel, Sherif Barakat, (2016) "Enhancing Big Data Value Using Knowledge Discovery Techniques", International Journal of Information Technology and Computer Science(IJITCS), Vol.8, No.8, pp.1-12, 2016. DOI: 10.5815/ijitcs.2016.08.01

[12] Meenakshim M, (2013), "Importance of ICT in Education", OSR Journal of Research \& Method in Education (IOSR-JRME)e-ISSN: 2320-7388,p-ISSN: 2320-737X Volume 1, Issue 4(May. -Jun. 2013), PP 0308

[13] Naidu, (2006) S. E-Learning: A guide of Principles, Procedures and Practices, 2nd. ed ed. Commonwealth Educational Media Centre for Asia, 2006.

[14] Stephanie Hirsh, Steve Higgins, (2010) Does ICT improve learning and teaching in schools? Newcastle University A Professional User Review of UK research undertaken for the British Educational Research Association.

[15] Sukanya Suranauwarat,(2017),"An Approach to Solving Technical Difficulties Facing Non-CS Students in a Database Class", International Journal of Modern Education and Computer Science(IJMECS), Vol.9, No.2, pp.14-26, 2017.DOI: 10.5815/ijmecs.2017.02.02

\section{Authors' Profiles}

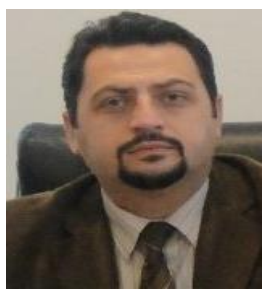

Bekim Fetaji is Full Professor of Informatics at University Mother Teresa - Skopje. Vice Rector for Science, former head of Research group in Programming and software Engineering and Formals specifications. Previously Dean of Computer Science Faculty and before that vice-dean for academic issues in computer Sciences. Received his $\mathrm{PhD}$ in Computer Sciences in Graz University of Technology with the dissertation thesis "E-learning indicators- a multidimensional model for planning, designing and developing e-learning software solutions". Previolsy finsihed his Master studies in Computer Science at Oxford Brookes University England UK. Main research interests are in software engineering, programming, data processing, technology enhanced education, web design, web development in java, software project management and closely related fields. Participated in several project teams within different programs such as Tempus, Erasmus and other national and international research projects. Published more than 100 scientific papers, mainly in international conferences and more than 20 international journals. The author can be contacted at bekim.fetaji@unt.edu.mk

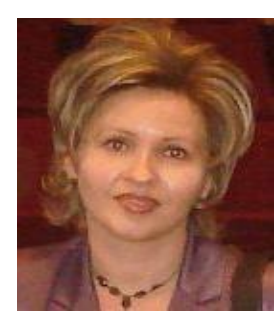

Majlinda Fetaji is an Associate Professor at the Faculty of Computer Sciences at South East European University -SEEU. She received her $\mathrm{PhD}$ in Computer Sciences at the Faculty of Contemporary Sciences and Technologies at South East European University -SEEU with the dissertation thesis "MAI instructional model, MLUAT testing methodology and TBMLM methodology framework for developing mobile learning software solutions". Her main research interests are algorithms and data structures, programming, e-learning, m-learning, virtual learning environments, and closely related fields. Awarded "Researcher of the year 2008" from the Macedonian Academy of Sciences for her research work in mobile learning and Technology Enhanced Education. Participated in different projects in Tempus, Erasmus and other national and international research projects. Head of the Quality Team of the Faculty of Computer Sciences. Published more than 60 scientific papers in international conferences and more than 20 international journals. The author can be contacted at m.fetaji@ seeu.edu.mk

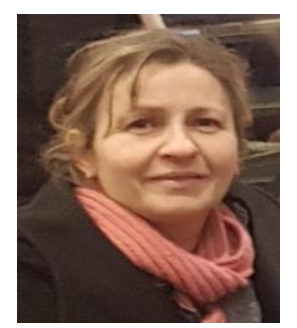

Mirlinda Ebibi is Assistant Professor of Informatics at University Mother Teresa - Skopje. Received her PhD in Computer Sciences at the Faculty of Computer Sciences in University of Novi Pazar with the dissertation thesis "Expert based learning methodology for developing mobile expert learning knowledge management software system". Main research interests are in programming, eLearning, m-Learning, technology enhanced education, web design, and closely related fields. Participated in several project teams within different national and international research projects. Published more than 50 scientific papers in international conferences and more than 20 international journals. The author can be contacted at mirlinda.ebibi@unt.edu.mk

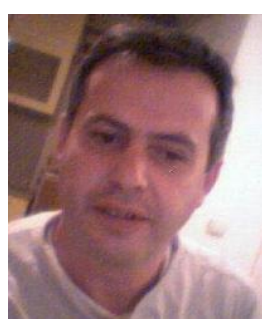

Samet Kera is Assistant Professor of Mathematics at University Mother Teresa - Skopje. Received his PhD in Mathematics at the Faculty of Natural Mathematical Sciences of Saint Cyril and Methodius University on Skopje. Main research interests are in Mathematics, math education, special interest in topology and closely related fields. Participated in several project teams within different national and international research projects. Published more than 30 scientific papers in international conferences and more than 10 international journals. The author can be contacted at samet.kera@unt.edu.mk 
How to cite this paper: Bekim Fetaji, Majlinda Fetaji, Mirlinda Ebibi, Samet Kera, " Analyses of Impacting Factors of ICT in Education Management: Case Study", International Journal of Modern Education and Computer Science(IJMECS), Vol.10, No.2, pp. 26-34, 2018.DOI: 10.5815/ijmecs.2018.02.03 